WASHINGTON, D.C.-A report entitled "U.S.-Japan Technology Linkages in Biotechnology" from the National Academy of Sciences (NAS, Washington, DC) Committee on Japan could almost be subtitled "Das Capital."

Warning that the U.S. biotechnology industry "could lose its competitive edge by the end of the decade," the NAS report views current bilateral arrangements between the U.S. and Japan as uneven and potentially very damaging from the U.S. standpoint-with domestic biotechnology companies and academic laboratories exchanging too much of their technical knowhow for desperately needed investment capital from Japan, but little else. "We need to be more aggressive so we get more than just capital from Japan," says Steven Burrill of Ernst \& Young (San Francisco, CA), who co-chaired the NAS panel that prepared the report. Moreover, the report warns that, if nothing is done, many U.S. biotechnology companies will disappear by the end of the decade, with a substantial and profitable portion of the industry surviving outside the U.S. Several similar warnings were sounded in a report, "Biotechnology in a Global Economy," issued last year by the Congressional Office of Technology Assessment (Bio/ Technology9:1318, Dec. '91).

\section{Cultural differences}

Important institutional and cultural differences between the U.S. and Japan work against the U.S. biotechnology industry, suggest some panel members. This concern extends beyond an appreciation-to near envy-for Japan's Ministry of International Trade and Industry (MITI). MITI's designation in 1981 of biotechnology as a key future technology for Japan did much to enhance the status of the country's efforts and to bolster the roles then played by the fermentation and pharmaceutical industries.

Informal cooperative arrangements among university, industry, and government scientists in Japan-arrangements that probably would not be tolerated in the U.S.-significantly augment MITI's contributions to biotechnology. Because virtually no one in Japan doubts the incorruptibility of key university professors, for instance, they are given substantially free rein to build coalitions, convene meetings, or even host lavish dinner parties if they deem such activities as beneficial to the country's biotechnology efforts. In the U.S., by contrast, such activities tend to be subject to more stringent standards of con-

\title{
U.S.JAPAN BALANCE
}

duct and to be scrutinized closely for potential conflict-of-interest violations.

Committee members, however, do not recommend breaking ties between the two countries to staunch the loss of critical biotechnology knowhow from the U.S. to Japan. "U.S.-Japan cooperation is inevitable and desirable," says committee member James Wyngaarden, who is NAS Foreign Secretary and the former director of the National Institutes of Health (Bethesda, MD). Instead of avoiding such ties, the report advises that deals be structured "to ensure U.S. participants gain clear benefits," and thus it outlines several examples of good and not-so-good deals. Similarly, when U.S. universities receive funding from Japanese companies, universities "should develop guidelines that ensure reciprocal access for U.S. researchers to the laboratories and knowhow of the sponsoring Japanese organizations," according to the report.

\section{Technology transfer}

"Technology transfer to Japan is far greater than expected," Wyngaarden notes. Besides formal exchanges between corporate partners, exchanges at scientific conferences, and exchange by publication in journals, a good deal of exchange is carried out informally, points out Burrill. Thus, there is a great deal of "unconscious transfer of technology, a lot of it by fax," he says, adding that the practice is especially widespread in universities where international information swapping arrangements are generally "done laissez-faire." The report advises researchers in universities and at companies to be more aware of the long-term consequences of such free-wheeling communication.

The report also cites as problematic the U.S. patent system, which operates on a different basis from those in Japan and Europe. The U.S. system judges patent applications on the first-to-in-

\section{JAPAN'S BIOTECH BUDGET (\$ Million)}

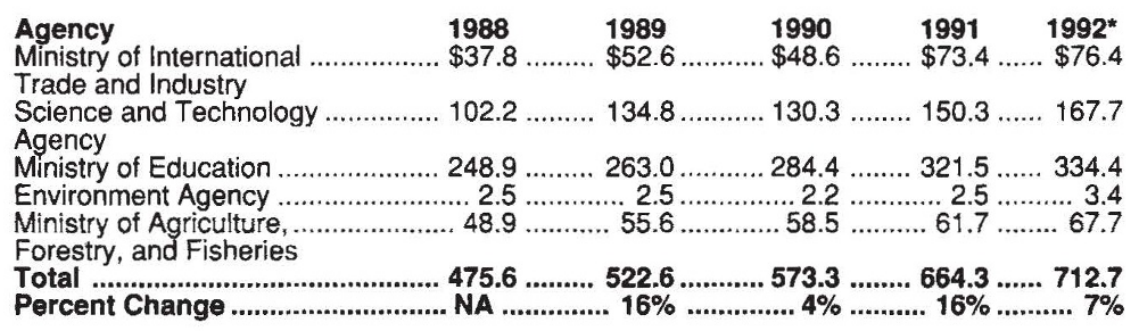

"Requested

Source: National Academy of Sciences's (Washington, DC) "U.S.-Japan Technology Linkages in Biotechnology"

\section{NO PEACE} UNEVEN INFO FLOW

TOKYO-There is to be no peace, it seems, between the U.S. and Japan when it comes to science and technology exchange. The current excitement focuses on the recently published National Academy of Sciences (NAS, Washington, DC) report, "U.S.Japan Technology Linkages in Biotechnology." The report calls attention to what its authors see as an uneven biotechnology information flow in Japan's favor.

The panel members' view is not entirely alarmist, but it does provide cause for concern. "The biotechnology information exchange between the U.S. and Japan is not equal, and is more in Japan's favor," agrees Isao Karube, professor of biotechnology at the University of Tokyo's Research Center for Advanced Science and Technology (RCAST). "The U.S. should spend more time and money collecting Japanese biotechnology information," adds Karube, a specialist in biosensor technology.
At the same time, observes Susan Clymer of Nichibei Bio (San Francisco, CA), the skewed flow of biotech information into Japan results partly from the aggressive efforts of U.S. firms to secure alliances with Japanese companies. "It's a buyer's bonanza," notes Clymer, describing how Japanese firms are visited by two or more technologytoting representatives of U.S. firms every day. "The Japanese companies don't even have to review the literature," says Clymer, who, like RCAST's Karube, confirms that "Japan makes much more effort to find out what's going on in the U.S. than the inverse."

Another area of concern in the NAS report is the close cooperation that exists between academia, industry, and government in Japan. "There is togetherness in Japan," acknowledges Clymer, "but it's overemphasized." Moreover, she continues, "Japanese professors don't initiate these consortia efforts. 
vent principle rather than the first-tofile system followed elsewhere. "Harmonizing the U.S. patent system with Europe and Japan is desirable," says NAS co-chair Hubert Schoemaker, who is chief executive officer of Centocor (Malvern,PA). Such an effort also would entail developing a better understanding of "what is and is not patentable," he says.

Seeing the U.S. biotechnology industry faced with this range of challenges, NAS panel members appeared uncomfortable trying to frame specific recommendations for changes in the U.S. system. Schoemaker says that a number of "very specific things could be done" through legislation "to reward innovators." Burrill points to a need for changes in the channeling of capital so that more consideration is given to longterm investment-and small company survival-in the U.S.

Panel members also say that a better effort is needed to bring disparate elements of the U.S. biotechnology effort into register. The administration's National Technology Initiative, coordinated by the National Institute of Standards and Technology (Gaithersburg, MD), marks a move in the right direction. The initiative encourages the transfer of federally developed technology to ind ustry. Other recent developments include the federal biotechnology budget initiative, which set aside $\$ 4$ billion for biotech research, and a broad endorsement of biotechnology by the administration's high-ranking Competitiveness Council. -Jeffrey L. Fox

They're brought in as adviseors and promoters of basic science." For example, when industry executives and the Ministry of International Trade and Industry think about doing something collectively, a key academician is identified as an academic "endorsement" for the line of research.

Given the imbalance in biotech accomplishment, could the U.S. benefit from Japan's existing strength in biotechnology? "The U.S. could get a lot of know-how from the Japanese biotech industry through cross-licensing or cooperative projects," says RCAST's Karube. In fact, notes Clymer, many U.S. firms could benefit substantially from Japanese firms. "A lot of U.S. companies have very sophisticated receptor-based assay systems for screening compounds," she says. "Japan has some of the largest natural-product libraries in the world. Where you'll see U.S. companies begin to benefit from Japanese research and technology will be in establishing alliances to utilize these libraries." -Stuart M. Dambrot

\section{QUIETLY AMASSING MILLIONS} s.

SANTA CRUZ, Calif.-It's still a rarity for a biotechnology company to turn a profit, especially when it's an agbiotech company. It's even rarer for a firm to achieve such a milestone without vigorously tooting its own horn. But such is Idexx Laboratories (Westbrook, ME), a "biodetection" outfit. The company cleared \$3.2 million last year and raised $\$ 30$ million in a secondary offering in April. Its stock has by and large resisted the often-severe drops that have recently affected the sector. And this despite the fact that, until quite recently, analysts didn't even follow the firm.

What's the formula? Can we attribute it to Yankee ingenuity? Oppenheimer (New York) analyst Glenn Reicin, who picked up on the stock in February, says that, "above all, this is a management story." Idexx president and founder David Shaw explains that the company's business strategy has remained consistent from its start in 1983. "We try to participate only in those markets where we have all the ingredients to be a market-share leader," says Shaw.

Shaw explains that Idexx targets markets that are too specialized or small to attract competiton from major companies. In animal health care, "large companies tend to focus more on drugs and vaccines than on diagnostics," he says. But one of the major problems in treating animal disease has always been to identify the causative agent early on.

So Idexx plunged into the animaldisease-diagnosis market. The company has also expanded into diagnostics to identify food and environmental contaminants. Today it sells over 70 products to both markets, to fit testing demands from high-volume-throughput laboratories to one-at-a-time users.

Idexx's first product was FlockChek, a computerized immunoassay system that monitors the health of flocks of chickens. Breeders monitor their flocks every few months by statistical sampling with assays that include about a dozen analytes for the major poultry pathogens, including Newcastle disease virus, infectious bursal disease virus, infectious bronchitis virus, and reovirus. From there, Idexx's animal-health product line expanded into livestock, and then into small animals and pets. The company now offers membrane-filterbased, non-instrumented test kits, using itsconcentration-immunoassay technology, to veterinary clinics and animal hospitals. It also sells instrument-based detection systems for testing large numbers of samples, mostly for disease surveillance and health monitoring in poultryand livestock. Oppenheimer's Reicin estimates that Idexx controls about 50 percent of the \$50-million animal-diagnostics market, and it dominates in areas like poultry testing.

One explanation for Idexx's rapid rise to profitability is that it has licensed or purchased much of its basic technology, instead of spending time and money to develop the technology itself. For example, the vast majorityof the company's products use modifications of available immunoassay-based detection methods. For high-throughput i m m unoassays, Idexx's technology of choice is a particle-concentration fluorescence immunoassay, which it licensed from Baxter International (Deerfield, IL). The lowerthroughput immunoassays use patented immunoassay technology licensed from Hybritech (San Diego, CA). The company also offers a DNA-probe-based assay that employs PCR technology licensed from Hoffmann-La Roche (Nutley, NJ). Additionally, Idexx has acquired product lines from Fermenta Animal Health (Kansas City, MO) and VetTest, a Swiss firm that specializes in blood-chemistry analysis.

Indeed, Idexx's product revenues have continued to swell. Between 1989 and 1990 , they jumped 41 percent, and they increased 23 percent from 1990 to 1991. How long can this earnings growth continue? Oppenheimer's Reicin foresees annual growth of 30 percent over the next three years; by 1995 he predicts Idexx will be a $\$ 110$-million company. And what will account for the growth? Idexx's Shaw comments: "People can expect in the future what they've seen in the past." Company growth has come largely from a proliferation of products; Idexx intends to maintain that approach, developing new products for existing markets while simultaneously expanding into hitherto untapped niches. 